\title{
BELAJAR ARIF MELALUI PEMBELAJARAN GURINDAM XII
}

\author{
Abdul Rozak \\ abdur-rozak58@fkip-unswagati.ac.id \\ Disajikan pada Seminar Internasional \\ Pendidikan Bahasa dan Sastra Indonesia \\ STKIP-NU Kaplongan-Indramayu, 13 Mei 2017
}

\section{TENTANG BELAJAR}

Manusia diciptakan Allah Subhanawataala dengan sempurna ("Sesungguhnya Kami telah menciptakan manusia dalam bentuk yang sebaik-baiknya," Q.S. 95: :4). Ia siap melakukan perintah Allah untuk memahami segala hal yang beredar di alam raya ini dengan tujuan beribadah. Semua yang diperolehnya, semua yang dikerjakannya hanya untuk mengenal Allah dan terus menyembah-Nya sepanjang hayatnya Belajar adalah proses untuk menemukan kemampuan yang diabdikan kepentingan ibadah kepada Allah (Dan Aku tidak menciptakan jin dan manusia melainkan supaya mereka menyembah-Ku" Al-Baqarah:21) Kemampuan dipupuk, dipilih, dikembangkan untuk kepentingan peningkatan kualitas menjalankan kehidupan.

Belajar menjadi kegiatan inti manusia. Tanpa belajar manusia tidak akan mampu menjalankan hidup dengan baik, dengan keteraturan dan dengan aman. Segala hal yang terjadi di dunia ini berakibat pada terdorongnya manusia mengetahui agar mampu menjalankan hidup dengan nyaman. Kenyamanan dapat diraih karena kita mengetahui apa yang harus dilakukan dalam hidup ini. Belajar harus berakibat pada kemampuan kita memahami diri dan lingkungannya. Belajar harus berdampak pada kualitas hidup bagi dirinya dan bagi lingkungannya. Makna belajar seperti ini merupakan kekuatan yang harus ditumbuhkan pada siswa secara sistematik semua pembelajaran di sekolah.

Sekolah menjadi media penting dalam mewujudkan kekuatan ini. Sekolah merancang segalanya dengan tertib, tertata, bertujuan, dan bersistem. Penyelenggaraan pendidikan dan pembelajaran di sekolah mempunyai dasar yang telah disiapkan dengan berbagai dasar yang dapat dipertanggungjawabkan, seperti kurikulum. Kurikulum merupakan pedoman menjalankan aktivitas pembelajaran bagi guru dan siswa." Kurikulum adalah seperangkat rencana dan pengaturan mengenai isi dan bahan pelajaran serta cara yang digunakan sebagai pedoman penyelenggaraan kegiatan belajar mengajar. Isi kurikulum merupakan susunan dan bahan kajian dan pelajaran untuk mencapai tujuan penyelenggaraan satuan pendidikan yang bersangkutan, dalam rangka upaya pencapaian tujuan pendidikan nasional." (UU Nomor 20 Tahun 2003 tentang Sisdiknas). Berdasarkan kurikulum ini guru dipacu untuk mencapai tujuan pendidikan nasional. Kewajiban guru sangat berat dengan memertimbangkan kewajiban yang tercantum dalam kurikulum. Tugas utama guru adalah menjadikan siswa sebagai menusia pembelajar.

Setiap gerakan pikir dan fisik guru harus berakibat pada terjadinya kondisi di kelas yang mendorong siswa berkeinginan belajar, termasuk pada pembelajaran sastra. Kewajiban utama guru adalah membangun komunikasi dengan para siswa yang akan menjadi bagian penting dalam kemajuan negara, bangsa, dan agama. Persiapan matang harus dilakukan agar tidak terjadi 
kesalahan-kesalahan seperti masa sebelumnya yang terlihat jelas pada kondisi sekarang. Anakanak kita tidak berperilaku seperti yang kita inginkan. Mereka berjalan seiring dengan desakan informasi bebas dari berbagai penjuru, sumber yang mudah diakses tanpa saringan.

Belajar menuju kualitas adalah ketentuan yang tidak dapat ditunda keharusannya. Ajakan secara sistematis kepada para siswa harus direncanakan guru dengan baik dan sebaik-baiknya, dengan benar menurut jalan benar. Niat dan cara adalah jalan menuju kebaikan. Tahapan-tahapan pembelajaran perlu dikenalkan guru kepada para siswa. Kita harus mengingatkan diri kita masing-masing bahwa siswa dalam kondisi pencarian untuk memenuhi dirinya. Mereka mencari segala hal yang menjadikan dirinya dapat bergerak dengan nikmat, dengan leluasa. Pergerakan siswa bukan untuk dibatasi, mereka perlu diberi tahu jalan menuju kebenaran dan kebahagian. Jalan-jalan yang terbentang di hadapannya luas dan berkelok-kelok. Kondisi seperti itu memberikan peluang kesesatan pada siswa. Bimbingan guru penting disistematikkan dalam pembelajaran yang terus-menerus dijalankan dengan tepat dan meyakinkan sehingga siswa mengikuti dengan ikhlas.

Unsur utama yang harus ditanamkan adalah akhlak, "“Sesungguhnya aku (Muhamaad) diutus tidak lain hanyalah untuk menyempurnakan akhlak yang mulia." (HR. Ahmad)." Perilaku baik tidak akan pernah merugikan dirinya dan orang lain. Hasil belajar sebaik apa pun, sebanyak apa pun, sekualitas apa pun tidak akan pernah berguna tanpa kendali akhlak. Akhlak menjadi indaktor untuk kegiatan apa pun karena perilaku dan periucap pada dasarnya bergantung pada akhlak. Pendidikan akhlak menjadi penting dan harus tujuan utama dalam pembelajaran. Praktik baik akhlak adalah dalam perilaku pembelajaran, “"Tidak ada sesuatu pun yang lebih berat dalam timbangan seorang mukmin di hari Kiamat melainkan akhlak yang baik, dan sesungguhnya Allah sangat membenci orang yang suka berbicara keji dan kotor." ( HR. AtTirmidzi dan Ibnu Hibban)". Guru dapat mempraktikkannya di hadapan para siswanya, melalu bahan ajar yang disusunnya dan salah satu bahan ajar itu adalah sastra.

Sastra memberikan peluang untuk dikembangkan secara seimbang antara pikiran dan hati. Karya sastra dibangun berdasarkan unsur pikiran dan niat para pengarangnya. Pilihanpilihan materi dan cara memberikan arahan kepada guru untuk membedah dengan sistematik menggunakan teori tertentu. Perilaku baik dapat diajarkan melalui sastra dengan menyenangkan. Guru mengajak siswa melalui sastra untuk belajar arif sehingga secara bertahap akhlak baik tertanam dalam diri siswa. Teladan adalah cara utama dalam pengajakan belajar arif dengan balutan pencapaian kompetensi yang diinginkan kurikulum 2013; spiritual, sosial, pengetahuan, dan keterampilan.

\section{MUATAN SASTRA DALAM KURIKULUM 2013}

Kurikulum disusun berdasarkan tujuan luas, berdasarkan kepentingan bangsa dan negara pada masa yang akan datang. Jangkauan masa jauh, masa yang diinginkan terjadi pada satu hari adalah karakter kurikulum pembelajaran. Kondisi masa kini menjadi acuan untuk menentukan tujuan pada masa yang akan datang. Kajian kurikulum berdasarkan ilmiah ditentukan dengan pertimbangan-pertimbangan yang matang untuk meminimalkan kekurangan-kekurangan yang terjadi pada perjalanannya. Indikator ketercapaain kurikulum dinyatakan dalam kompetensi yang 
terdiri atas kompetesi spiritual, kompetensi sosial, kompetensi pengetahuan, dan kompetensi keterampilan.

Tujuan utama tercantum pada kompetensi inti 1 (spiritual), yaitu "Menghayati dan mengamalkan ajaran agama yang dianutnya". Cara mencapainya diuraikan melalui kompetensi inti 2 (sosial), yaitu"Menghayati dan mengamalkan perilaku jujur, disiplin, tanggung jawab, peduli (gotong royong, kerja sama, toleran, damai), santun, responsif dan pro-aktif dan menunjukkan sikap sebagai bagian dari solusi atas berbagai permasalahan dalam berinteraksi secara efektif dengan lingkungan sosial dan alam serta dalam menempatkan diri sebagai cerminan bangsa dalam pergaulan dunia". Kondisi yang diharapkan terjadi pada masyarakat kita adalah semua warga Indonesia menjalankan ajaran agamanya dengan baik, tidak saling menganggu, tidak saling menyalahkan, damai dan sejahtera. Sasaran diarahkan pada kondisi kebatinan, kesejahteraan yang dapat mengalir pada kondisi lahir. Tentu tujuan ini baik bagi semua. Agama tidak pernah mengajurkan kejelekan, pertengkaran, pertentangan. Kondisi yang terjadi pada masa kini adalah kemampuan penganutnya yang tidak menjelaskan posisi sebagai penganut di bawah ajarannya. Ada penganut yang tidak memahami cara menjalankan ajran agamanya dengan baik, tidak menganggu orang lain, apalagi menghina dan melecehkan dan merendahkan. Kata toleransi itu disalahgunakan, dimanfaatkan untuk kepentingan golongannya. Padahal jika semua penganut agama menjalankan ajarannya, tidak akan terjadi peristiwa yang tidak diinginkan, seperti penistaan terhadap agama. Orang yang berperilaku ini tidak memahami bagaimana menjalankan ajarannya.

Toleransi dalam Islam telah jelas dan terang, bahwa hanya dalam hal interaksi, dalam bertetangga, bukan dalam hal ibadah. "Allah tiada melarang kamu untuk berbuat baik dan berlaku adil terhadap orang-orang yang tiada memerangimu karena agama dan tidak (pula) mengusir kamu dari negerimu. Sesungguhnya Allah menyukai orang-orang yang berlaku adil" (QS.Al-Mumtahah: 8)Sumber: http://muslim.or.id/23967-bukti-toleransi-islam-terhadap-agamalainnya.html). Umat Islam diwajibkan berbuat baik kepada siapa pun, tidak terbatas pada sesamanya, tentu dengan batasan-batasan tertentu yang sangat jelas. Peristiwa di bawah ini adalah contoh nyata toleransi dalam Islam.

Kompetensi inti 1 (spiritual) dijabarkan pada kompetensi inti 2 (sosial). "Menghayati dan mengamalkan perilaku jujur, disiplin, tanggung jawab, peduli (gotong royong, kerja sama, toleran, damai), santun, responsif dan pro-aktif dan menunjukkan sikap sebagai bagian dari solusi atas berbagai permasalahan dalam berinteraksi secara efektif dengan lingkungan sosial dan alam serta dalam menempatkan diri sebagai cerminan bangsa dalam pergaulan dunia”. Sejumlah perilaku yang disarankan, yang ditargetkan pada kompetensi inti 2 (sosial) mencakup sebagai bagian penting dalam berinteraksi. Jika perilaku itu dimiliki siswa selama 3 tahun, insya Allah kondisi lingkungan akan kondusif, tidak ada lagi kerusakan sosial, kekerasan, dan segala perilaku yang membuat bangsa ini tidak bermartabat. Tugas guru berkaitan dengan pencapaian perilaku-perilaku yang tercantum pada kurikulum.

Kurikulum berharap siswa mampu mengamalkan perilaku jujur, misalnya. Kata jujur sering diucapkan karena begitu pentingnya, begitu inginnya terjadi dalam setiap kondisi. Akan tetapi, hal sulitnya diwujudkannya. Diucapkan terus dalam setiap aktivitas, dalam setiap persyaratan terus dimasukkan. Cara ini menjadi khawatir karena seolah jujur itu hanya diucapkan. Ucapan memeroleh kekuatan bila diikuti dengan cara mewujudkannya, dikawal dengan instrumen. Kita sering lupa setelah melontarkan gagasan kepada khalayak, kepada sasaran, setelah itu selesai. Kita lupa bahwa gagasan itu tidak dapat terwujud dengan sendirinya. Gagasan perlu diberi jalan menuju keberhasilannya. Apa yng 
dibutuhkan agar gagasan itu menjadi kenyataan. Kerja berat adalah mengawal gagasan itu karena banyak pihak yang terlibat.

Guru wajib mencermati perilaku lain yang dicantumkan pada KI-2, yaitu (2) disiplin, (2) tanggung jawab, peduli (gotong royong, kerja sama, toleran, damai), (3)santun, (4) responsif dan proaktif, (5) dan menunjukkan sikap sebagai bagian dari solusi atas berbagai permasalahan dalam berinteraksi secara efektif dengan lingkungan sosial dan alam serta dalam menempatkan diri sebagai cerminan bangsa dalam pergaulan dunia”. Lima perilaku itu sasaran yang sulit. Pencapaianya memerlukan kajian matang, pendekatan multidisiplin, dan terutama kekuatan untuk mewujudkannya. Kemampuan kita harus diikuti dengan kekuatan untuk mewujudkannya. Banyak teori yang telah dicakapkan, diutarakan dalam berbagai bentuk kepada komunitas tertentu atau situasi tertentu, tetapi tidak terjadi karena tidak dikuatkan dengan kemauan memiliknya. Keberhasilan selalu merupakan paduan kekuatan gagasan dan kemampun untuk mewujudkannya. Gagasan itu seharusnya diniatkan untuk menuju kebaikan. Kompetensi inti yang dituangkan pada kurikulum 2013 bukan sekedar pajangan. Kompetensi disiapkan sebagai pedoman dalam penyelenggaraan pembelajaran dan pendidikan di sekolah dan di kelas khususnya.

Penyelenggaraan pembelajaran adalah tugas utama guru yang seharusnya memiliki kompetensi personal, sosial, akademik, dan pedagogiknya. Keteguhan, ketaatan terhadap asas keilmuan dan kebijakan dalam bentuk aturan harus dijadikan dasar dalam penyelanggaraan pendidikan dan pembelajaran di kelas. Guru merupakan penguasa di kelas. Guru dapat menentukan arah perjalanan hidup siswa pada masa yang akan datang. Butir-butir yang terdapat pada kompetensi inti 2 (sosial) merupakan jangkauan masa kini dan masa depan. Kepemilikan butir-butir kompetensi itu dapat menjamin kekuatan siswa dalam nenjalankan hidup. Oleh karena itu, guru harus bersungguh-sungguh menuangkan dalam bentuk pembelajaran yang dapat merespons siswa untuk memahami dan menerapkannya dalam bentuk perilaku dan peri kata sehari-hari.

Pencapaian kompetensi itu dijalankan melalui muatan mata pelajaran. Kurikulum menyusun keteraturan melalui tahapan. Penjabaran kompetensi inti (1) dijabarkan dalam kompetensi inti 2 (sosial) dan yang harus diterjadikan guru di kelas adalah kompetensi inti 3 dan 4 dan (kompetensi pengetahuan dan keterampilan). Bagaimana dengan muatan sastra dalam kurikulum bahasa Indonesia, apakah dapat mendukung ketercapaian kompetensi inti 1 dan 2?

Kajian difokuskan pada kurikulum 2013 SMA (kelas X-XII). Kajian diarahkan pada keterhubungan antara kata kerja operasioal yang terdapat pada KD kompetensi inti 3 dan KD yang terdapat pada kompetensi inti 4). Titik pusatnya adalah keterkaitan, keterhubungan antara kata kerja itu dengan objek yang dijadikan sasaran kegiatan. Bentuk kegiatan yang diharapkan terjadi pada pengalaman bersastra para siswa serta yang utama adalah hubungan pembelajaran sastra itu terhadap pencapaian kompetensi inti 1 dan 2. Setelah kajian akan dibahas keterkaitannya dengan perilaku baik siswa, sikap arif siswa sebagai akibat dari kepahamannya dalam beraktivitas sastra.

Apa yang diprediksi kurikulum agar siswa memeroleh perilaku arif, perilaku baik? Secara normatif kurikulum mencantumkan teks narasi yang meliputi hikayat, cerita rakyat, cerita pendek, novel, drama, cerita sejarah, puisi. Semua teks sastra dijadikan sebagai media pencapaian kompetensi inti; kompetensi spiritual dan kompetensi sosial. Perilaku belajar yang diharapkan terjadi dipolakan pada kompetensi dasar. Secara jalur kurikulum menyusun kompetensi dasar yang di dalamnya tercantum materi pokok sebagai bahan kajian yang diharapkan guru mampu menerjadikan pembelajaran untuk memeroleh kompetensi dasar yang direncanakan. Pada posisi inilah guru harus mempu membaca untuk 
menafsirkan maksud KD kemudian menerjemahkan dalam bentuk langkah-langkah pembelajaran sastra. Kejelian guru dibutuhkan untuk menjabarkan dengan benar.

Di bawah ini dikutipkan beberapa contoh kompetensi dasar yang berhubungan dengan sastra kemudian diikuti dengan kajian yang mengarah pada kemungkinan menggunakan materi lain yang berpotensi memudahkan tertanamkannya sifat arif siswa. Muatan sastra pada kurikulum tidak lengsung mengarah pada pembentukan perilaku arif, jujur, disiplin, misalnya. Guru yang harus menentukan rangkaian peristiwa di kelas yang berkandungan kemauan siswa menemukan makna. Olahan guru harus dirancang dengan memerhatikan sebab dan berakibat pada kehalusan budi siswa pada saat dan setelah pembelajaran dilaksanakan dan lebih utama adalah perilaku baik itu tertanam pada siswa. Menciptakan kondisi seperti itu tidak mudah, perlu perjuangan tanpa lelah dan tanpa putus. Kelelahan guru biasanya menjadi kebahagian bila para siswa mampu memerlihatkan perilaku baik yang dirindukan guru dan masyarakat pada umumnya.

Langkah pertama, guru memahami muatan sastra yang berpotensi pada perilaku baik siswa. Pada tahapan ini guru menetapkan kompetensi dasar yang dijadikan sebagai media pencapaian perilaku baik. Di bawah ini dituliskan beberapa KD (kompetensi inti pengetahuan dan kompetensi inti keterampilan).

3.7 Mengidentifikasi nilai-nilai dan isi yang terkandung dalam cerita rakyat (hikayat) baik lisan maupun tulis

4.7 Mengembangkan makna (isi dan nilai-nilai) dalam cerita rakyat (hikayat) baik secara lisan maupun tertulis dalam bentuk teks eksposisi

Kedua kompetensi di atas berhubungan bersifat ketergantungan dan berkelanjutan. Kompetensi dasar 3.7 menjadi landasan tercapainya KD 4.7. Hubungan kedua KD itu dapat dicermati pada penggunaan kata kerja operasional. Pada KD 3.7 dituliskan kata kerja operasional mengidentifikasi dan pada KD 4.7 digunakan kata kerja operasional mengembangkan. Hubungan kedua kata kerja operasional merujuk pada keberlanjutan tindakan. Tindakan mengembangkan tidak mungkin dilaksankan tanpa menyelesaikan tindakan mengindentifikai. Kata idenfikasi merujuk pada kegiatan yang mencari, menemukan, mengumpulkan, meneliti, mendaftarkan, mencatat data dan informasi dari "kebutuhan" lapangan. Target kegiatan mengidentifikasi adalah temuan rincian objek, sesuai dengan tujuan mengindentifikasi, seperti contoh di atas mengidentifikasi nilai-nilai da isi yang terkandung dalam cerita rakyat. Target mengidentifikasi adalah nilai dan isi. Jadi, mengidentifikasi berhasil jika diperoleh nilai dan isi. Perolehan kegiatan itu dalam bentuk informasi yang berhubungan dengan objek yang diteliti. Jadi, kegiatan mengidentifikasi di atas adalah pada akhirnya tercatat, terdokumentasi informasi tentang nilai dan isi yang terdapat pada tels cerita rakyat. Siswa diharapkan memiliki kemampuan memahahi informasi yang terdapat pada teks yang ditelaahnya. Kompetensi ini berhubungan dengan kompetensi yang harus dimiliki pada kegaiatan berikutnya, yaitu "Mengembangkan makna (isi dan nilai-nilai) dalam cerita rakyat (hikayat) baik secara lisan maupun tertulis dalam bentuk teks eksposisi." Kompetensi ini tidak akan diperoleh sebelum siswa memeroleh kopetensi pada KD 3.7. Kegiatan mengembangkan membutuhkan butir-butir yang dikembangkan. Makna yang dimaksudkan pada KD itu adalah nilai-nilai dan isi yang terdapat pada teks cerita rakyat. Siswa tidak akan dapat menulis teks eksposisi tanpa mengetahui isi teks cerita rakyat. Dengan posisi ini pembelajaran harus dilaksanakan dalam konteks dan konsep kebersamaan berpikir dan berimajinasi. Menulis selallu bersyaratkan gagasan, apa yang diketahui karena menulis bertujun dasar memberi tahu. 
Oleh karena itu, sebuah proses yang panjang harus disiapkan guru dalam berusaha membawa siswa ke arah berkemampuan mengembangkan isi dan nilai dalam bentuk ekposisi.

Permintaan kurikulum 2013 disusun seperti itu. Integrasi antara kemampun disusun berhubungan dengan erata dan bersyarat. Sistem ini dapat dipahami dari sisi hakikat belajar sebagai peristiwa. Pembelajaran dimaknai sebagai sebuah proses berkelanjutan, tidak pernah selesai, selama hayat dikandung badan. Menata rangkaian belajar adalah tugas utama guru karena pada hakikatnya guru sedang menata jalan hidup para siswanya. Masa depan disusun sebagai kondisi yang diharapkan diinginkan siswa; kondisi bahagia dan membahagiakan, sejahtera dan mensejahterakan.

Apakah muatan sastra dalam kurikulum merujuk pada kekuatan diri dalam menghadapi hidup yang kompleks. Bahan ajar yang disusun merupakan tanggung jawab guru. Kurikulum menyiapkan garis besar yang dapat menuntun guru mencapai tujuan yang telah ditentukan, yang dwujudkan dalam bentuk kompetensi inti (spiritual, sosial, pengetahuan, dan keterampilan). Tanggung jawab guru adalah mengembangkan dengan penuh perhatian, fokus pada masa depan. Di bawah ini dianalisis muatans sastra yang berbeda dengan contoh di atas, akan tetapi polanya tidak berbeda. Artinya kurikulum memolakan aktivitas siswa itu dengan ketentuan pelanjutan penguasaan satu kompetensi ke kompetensi lainnya. Pola ini diharapkan memolakan juga pola pikir guru pada saat membimbing para siswa mencapai kompetensi tertentu. Pemahaman guru atas pola kurikulum menjadi kekuatan pencapaian kompetensi yang diharapkan. Kurikulum merupakan konsep. Ia membutuhkan tindak lanjut. Pada kondisi inilah terjadi masalah yang dapat berkembang menjadi lebih baik atau sebaliknya. Guru dan masalah adalah kekuatan yang akan menagrahkannya berpikir menjadi lenih baik atau berbalik menjadi tumpukan masalah bila guru tidak memahami bagaimana mengubah masalah menjadi energi. Pada sisi inilah dibutuhkan guru yang kreatif tanpa henti, tidak bosan berinovasi, tidak cepat puas, terus menggunakan pikirannya untuk kepentingan masa depan para siswanya.

Kompetensi di bawah ini mendorong kegiatan guru menyiapkan kekuatan ilmu dan praktik untuk membawa siswa pada kegiatan bermakna.

3.7 Menemukan butir-butir penting dari satu buku fiksi (buku kumpu

4.7 Menyusun laporan butir-butir penting dari satu buku fiksi (buku kumpulan cerpen) yang dibaca.

Tugas guru adalah menjadikan para siswa memiliki kompetensi memahami isi buku fiksi dan berdasarkan pemahaman itu siswa dapat menyusun laporan butir-butir penting yang terdapat pada cerpen itu. Butir-butir cerita fiksi hanya dapat diperoleh melalui membaca. Kegiatan membaca tidak dapat dianggap sebagai pelengkap. Kompetensi dasar itu mempunya kata kunci yang harus dianalisis guru dengan cara memaknai dan menghubungkan antara kata kunci tersebut. Rangkaian belajar selalu mempunyai hubungan sejak awal. Prinsip belajar adalah kegiatan yang tidak putus dan berhubungan satu sama lan. Proses belajar selalu penghubungan antara topik yang sedang diajarkan dengan topik yang telah diajarkan dan topik yang akan diajarkan.

Kompetensi dasar 3.7 memuat kata kerja operasional menemukan. Kata menemukan 
mempunyai arti "mendapatkan sesuatu yang belum ada sebelumnya". Arti kata menemukan merujuk pada proses memeroleh sesuatu berdasarkan kegiatan menganalisis, mengkaji, dan meneliti. Kegiatan ini memerlukan bekal ilmu yang cukup, daya pikir yang terlatih, dan kemampuan memilih serta menyimpulkan. Proses mendapatkan sesuatu yang belum ada harus dimulai dari tujuan yang berbentuk wujud yang dapat dipahami, misalnya menemukan ciri-ciri cerpen Indonesia Angkatan 2000-an. Kegiatan ini baru dilaksanakan kali ini. Para siswa belum mengetahui ciri-ciri cerpen Indonesia Angkatan 2000-an. Mereka dikenalkan tahapan memahami cerpen dengan cara benar, melalui praktik baca. Kegiatan praktik akan melandasi termilikinya kompetensi mengetahui. Kegiatan berproses ini dapat berjalan dengan baik bila guru memahami makna cerpen dengan baik. Guru berpengalaman membaca cerpen, karena pembelajaran adalah bagaimana memberi tahu apa yang seharusnya diketahui oleh guru berdasarkan pengetahuan yang dimiliki guru. Kepemilikan pengetahuan guru melalui pemahaman teori dan praktik sehingga pembelajaran berjalan dengan baik karena petunjuk telah tersedia pada guru. Guru bertanggung jawab penuh selama di kelas. Persiapan mengajar mengacu terhadap pemikiran yang kompleks karena berbagai pikiran yang mempengaruhi putusannya.

Proses menemukan cirri-ciri cerpen di atas memunculkan rangkaian tindakan yang harus dilakukan guru yang akan berakibat pada kegiatan siswa di kelas. Pada bagian selanjutnya penulis akan memaparkan langkah-langkah guru sebelum mengajar dengan fokus pada ketercapaian perilaku baik yang berlandaskan penjalanan agama yang dianutnya. Langkahlangkah ini hanya berhubungan dengan pembelajaran sastra. Usaha guru menjadikan teks sastra berpengaruh terhadap perilaku siswa. Tujuan yang akan dicapai bersifat implikasi, yaitu tujuan sampingan. Tujuan sampingan ini dipengaruhi oleh ketercapaian tujuan instruksional. Guru yang bertanggung jawab akan memikirkan rencana masa depan hidup para siswanya. Penataan bahan ajar, misalnya direncanakan untuk mencapai tujuan intruksional. Pada saat menyusun tujuan intruksional, guru berpikir jauh untuk menata perilaku anak yang akan hidup pada masa yang akan dating. Penyusunan tujuan intruksional dipikirkan untuk menjangkau kemampuan siswa yang melebih keinginan kurikulum. Dengan demikian, guru yang menentukan kemampuan yang akan dimiliki para siswa. Kadar kompetensi ditentukan usaha guru. Kurikulum tidak dapat menentukan perilaku siswa secara praktik. Kurikulum menentukan kompetensi yang harus dimiliki siswa secara konsep.

Pada paparan berikutnya adalah dua kegiatan penting yang harus dilakukan guru, yaitu pemilihan bahan kajian dan penentuan kegiatan siswa. Kedua aktivitas guru ini sangat penting karena aktivitas ini menentukan masa depan siswa. Berdasarkan kegiatan ini dapat dibaca apa yang diinginkan guru agar siswa memiliki perilaku baik dan bagaimana cara mencapainya. Oleh karena itu, guru profesional akan bersungguh-sungguh menentukan kegiatan ini.

\section{MEMILIH BAHAN PEMBALAJARAN}

Perbincangan di kelas didominasi penguasaan bahan yang dijadikan media untuk mencapai kompetensi tertentu. Interaksi akan berjalan jika terdapat bahan yang dibicarakan. Kualitas interaksi ditentukan oleh bahan yang dipilih guru dengan beberapa pertimbangan. Fokus guru dalam kegiatan ini sangat penting. Kegagalan pembelajaran bermula dari kegagalan memilih bahan. Respons siswa ditentukan oleh pilihan bahan. Reaksi siswa tergantung pada penentuan bahan ajar. Jika bahan ajar yang dipilih menarik siswa, pembelajaran akan berjalan dengan baik. Oleh karena itu, guru perlu memertimbangkan berbagai aspek pada saat memutuskan pilihan bahan. 
Pertama, keluasaan dan penguasaan guru terhadap bidang kajian pembelajaran. Pilihan bahan ajar dimulai dengan kemampuan menafsirkan kompetensi inti dan kompetensi dasar yang terdapat dalam kurikulum. Tafsiran dapat dilakukan dengan baik dengan penguasaan ilmu. Ilmu dapat membaca maksud yang terdapat dalam kurikulum. Pikiran akan bekerja dengan leluasa dan cepat. Penguasaan ilmu secara baik akan mempercepat proses penguasaan. Inti bahan kajian adalah pertanggungjawaban dari segi keilmuan. Guru bahasa Indonesia dituntut menyusun bahan ajar yang dapat memberikan gambaran dengan jelas kegiatan kelas yang sesuai dengan harapan kurikulum. Kejelasan rencana pembelajaran hanya dapat dilakukan dengan dasar penguasaan ilmu yang baik. Penguasaan ilmu berhubungan dengan latar belakang guru yang tepat. Guru dilahirkan dari lembaga keguruan yang mendidiknya di bidang ilmu bahasa Indonesia atau Fisika, Biologi, atau bahasa Inggris. Pendidikan yang telah diukur dalam waktu tertentu, dengan kurikulum teruji, dengan paduan teori, dan praktik. Kondisi ini mencerminkan harapan kualitas pembelajaran yang diinginkan dapat terjadi.

Guru dituntut dapat membaca kurikulum dengan baik agar dapat menjabarkannya dalam bentuk proses pembelajaran di kelas. Kelas adalah tempat yang kompleks, yang dapat memunculkan ragam masalah. Masalah itu muncul tanpa dapat dihindari karena keragaman siswa sebagai pembelajar, keragaman harapan dari orang tua dan pemerintah. Masalah itu tidak boleh muncul. Guru harus berposisi sebagai pemecah masalah. Pikiran guru harus berisi ribuan solusi. Kedudukan guru diharapkan dapat membantu siswa menemukan keinginannya, harapannya, masa depannya. Guru bermasalah akan menghilangkan harapan dan akan meluluskan murid bermasalah. Kondisi ini dapat dihindari dengan kemampuan guru mengelola bahan dan mengelola kelas. Pengetahuan luas yang dipadu dengan pengalaman berkualitas akan memandu guru membawa para siswanya ke jalan yang benar dengan cara yang benar. Bahan kajian sebagai media bermakna jika mendorong siswa melakukan kegiatan bermakna dan bermafaat bagi peningkatan hidupnya.

Kedua, tujuan sebagai dasar pilihan. Tujuan pembelajaran selalu mengarah pada pemilikan kompetensi tertentu. Keputusan guru memilih bahan ajar ditentukan oleh tujuan yang ingin diicapainya. Pikiran guru harus selalu berorientasi pada kegiatan siswa yang dapat diterjadikan di kelas. Kurikulum telah menentukan ragam tujuan yang dipolakan tercapai pada waktu tertentu. Ragam tujuan yang disiapkan merupakan harapan terwujudnya kompetensi siswa secara utuh. Oleh karena itu, guru harus memahami secara keseluruhan tujuan kurikulum yang dijabarkan dalam bentuk tujuan pembelajaran. Bahan ajar dipilih dengan pertimbangan ketercapaian tujuan secara bersama-sama. Pada saat guru menentukan bahan berdasarkan kompetensi inti (3/pengetahuan)" Menganalisis aspek makna dan kebahasaan dalam teks biografi (3.15)", banyak hal yang harus dipikirkan. Guru memikirkan teks biografi. Teks biografi bertebaran yang sudah dipublikasikan. Ketepatan penentuan teks biografi melalui proses panjang. Pertama, guru membaca puluhan teks biografi yang diperkirakan cocok untuk siswa SMA dengan memperhatikan kriteria. Kedua, guru membaca secara komprehensif, analisis, dan kritis. Ketiga, guru menguji teks yang telah dipilih. Guru menganalisis teks biografi. Kegiatan ini untuk mengukur kemampuan siswa. Keempat, pilihan teks diutamakan sesuai dengan 
kompetensi inti spiritual dan sosial. Kompetensi inilah (KI-1 dan KI-2) yang menjadi dasar pilihan teks biografi, yaitu menganalisis makna. Acuan ini akan memudahkan guru dan siswa berinteraksi di kelas dalam upaya mewujudkan kepemilikan kompetensi yang telah ditargetkan. Perilaku guru dan siswa selalu diarahkan pada konteks pencapaian kompetensi. Arah yang benar mudah mencapainya.

Ketiga, prediksi kemampuan pemahaman siswa. Guru profesional mempunyai kemampuan memprediksi pemahaman yang harus dimiliki siswa. Prediksi itu memerlukan timbangan yang matang berdasarkan ketentuan pasti, sesuai dengan keilmuan. Guru telah memperhitungkan karakter siswa yang menajadi subjek pembelajaran. Segala yang berhubungan dengan siswa telah menajdi bagian tidak terpisahkan dari pribadi guru. Guru berada di kelas untuk kepentingan siswa. Karakter siswa menyangkut juga kemampuan intelektual dan spiritual siswa. Perpaduan antara pikiran dan perasaan memudahkan menanamkan perilaku tertentu kepada siswa. Keseimbangan ini merupakan bagian penting dalam proses pembelajar menuju pemilikan pemahamam. Tahapan-tahapan mencapai pemahaman berhubungan dengan penguasaan guru yang berhubungan dengan bahan kajian dan kata kerja operasional yang mendahuluinya. Jika kompetesi dasar "Menceritakan kembali isi teks biografi (4.15)", guru menyusun strategi yang berisi langkah-langkah mencapai tujuan agar siswa memiliki kemampuan menceritakan. Kemampuan menceritakan berhubungan dengan teori. Siswa perlu dibekali dengan pengetahuan menceritakan dan tata cara menceritakan. Pemahaman teori ini dinyatakan dalam bentuk penerapan dengan memberikan tugas kepada guru untuk menceritakan kembali isi teks biografi. Tahapan pencapaian tujuan ini dirancang guru dengan mempertimbangkan kemampuan dasar siswa, tingkat kesulitan bahan cerita, dan alokasi waktu serta instrumen untuk mengetahui tingkat pemahaman siswa. Langkah-langkah yang disusun guru berisi prediksi pencapaian pemahaman siswa, misalnya menceritakan kembali isi teks biografi.

Keempat, aktivitas siswa sebagai target. Aktivitas dalam pembelajaran merupakan bagian inti. Aktivitas memberikan berbagai kemungkinan perolehan pengalaman, pengetahuan, dan keterampilan termasuk dampak sampingan, yaitu diperolehnya perilaku. Pemerolehan perilaku ini dirancang melalui berbagai kegiatan dalam usaha pencapaian tujuan pembelajaran. Aktivitas terjadi karena hubungan akrab antara guru dan siswa. Hubungan unsur pembelajaran, guru dan siswa, menjadi usnur penting karena salah satu di antara tidak sejalan, aktivitas pembelaajran berhenti. Di antara dua unsur itu yang utama adalah guru. Guru menjadi penentu arah kegiatan di kelas. Pengalaman, pengetahuan, sikap, dan niat guru mewarnai kegiatan di kelas. Kualitas guru menentukan kualitas kegiatan yang terjadi di kelas. Oleh karena itu, guru perlu menyusun rangkaian kegiatan pembelajaran yang berhubungan dengan tujuan pembelajaran dengan media bahan ajar. Bahan ajar berperan penting karena ia menjadi bahan kajian, bahan diskusi antara guru dan siswa serta antara siswa. Kekuatan bahan ajar tidak dapat dipungkiri. Aktivitas pembelajaran adalah usaha siswa memahami bahan ajar sebagai usaha penguasaan kompetensi tertentu. Kompetensi“"Menceritakan kembali isi teks biografi (4.15)” dapat diperoleh siswa dengan perantaraan bahan ajar yang dapat memberikan rangsangan kepada siswa untuk berinteraksi. Interaksi jalan menuju pemerolehan kompetensi yang diharapkan dimiliki siswa. 
Siswa dapat membincangkan teks biografi jika siswa tertarik. Teks biografi yang biasa saja tidak mungkin dapat menarik siswa untuk membacanya dan membincangkannya. Oleh karena itu, pemilihan bahan ajar menentukan interaksi yang akan terjadi. Guru menyusun tahapan secara jelas. Langkah-langkah pembelajaran sebetulnya telah terpola. Secara sederhana pola pembelajaran terdiri atas pendahuluan, inti, dan penutup. Tahapan itu dapat diisi dengan berbagai kegiatan yang diperlukan guru sesuai dengan kebutuhan pembelajaran. Pendahuluan dapat menentukan kegiatan secara keseluruhan. Pembuka pembelajaran yang dirancang dengan baik akan memberikan peluang kepada siswa untuk mengikuti pembelajaran dengan penuh perhatian. Perhatian ini adalah unsur penting dalam pembelajaran. Pemeliharaan perhatian siswa harus diutamakan guru. Media dan model pembelajaran harus berorientasi terhadap usaha memunculkan perhatian dan pemeliharaannya hingga akhir pembelajaran. Kegiatan dan perhatian menjadi inti pembelajaran. Kedua unsur ini seharusnya dapat dilakukan dengan kesamaan niat antara guru dan siswa. Sekali lagi yang dapat memunculkan niat baik siswa adalah niat baik guru. Guru harus mengajar dengan hati. Insya Allah kegiatan pembelajaran akan berjalan dengan baik.

Kelima, niat. Mengapa guru menyelenggarakan pembelajaran? Alasan pertama adalah tugas. Guru ditugasi kepala sekolah membimbing siswa memeroleh kompetensi tertentu setiap menyelenggarakan pembelajaran secara tetap. Guru mengadakan pembelajaran berdasarkan kurikulum yang berlaku. Hak guru adalah masuk kelas dan di kelas dia wajib mengajar para siswa dengan sistem tertentu dan cara tertentu. Alasan kedua adalah mendewasakan para siswa. Guru bertugas membawa para siswa ke alam mandiri. Guru mengajari siswa bagaimana menjalankan hidup dengan baik. Sekolah dijadikan sebagai tempat menimba pengetahuan, pengalaman, dan keterampilan serta bersikap dalam hidup yang sebenarnya. Kelas menjadi tempat belajar hidup dengan benar. Oleh karena itu, guru yang mengajar dengan alasan formal tidak akan memeroleh kebahagian. Guru yang berbahagia pada saat mengajar akan menular pada bahagianya siswa pada saat belajar. Kondisi bahagia hanya dapat diperoleh dengan mendahulukan kegiatan hati dibandingkan dengan kegiatan fisik. Jadi, niat guru mengajar yang datang dari hati akan menjadikan suasana kelas pun ceria; tidak ada keluhan, tidak ada kemarahan, tidak ada kemalasan. Niat menjadi penting dikedepankan dalam pembelajaran. Guru harus membangun semangat belajar siswa melalui sentuhan hati, sentuhan kasih sayang. Niat yang baik akan berpengaruh terhadap pilihan bahan ajar. Guru akan memlilih bahan ajar yang menjadikan siswa dapat bercermin, dapat belajar menjadi orang baik.

\section{BELAJAR ARIF DALAM KEGIATAN BERSASTRA}

Tomlinson (2013:95-99) menyarankan salah satu unsur penting dalam mengembangkan bahan ajar adalah learning to learn. Kata belajar itu mengisyaratkan penting untuk dibelajarkan. Belajar hanya diperoleh dengan baik dalam proses pembelajaran. Belajar dalam tatanan proses belajar terkadang dilupakan guru. Fokus guru sering pada penguasaan materi ajar. Penilaian dikonsentrasikan pada penguasaan materi ajar. Fokus ini dapat dipahami karena mudah mengukurnya. Belajar mengarah pada proses pemeroleh kompetensi oleh siswa. Bagaimana cara 
siswa memeroleh kompetensi itu termasuk di dalamnya makna belajar menemukan dan memeroleh sesuatu.

Guru berkewajiban menyusun langkah-langkah yang memberikan peluang kepada siswa belajar dalam proses pembelajaran. Di samping memeroleh isi, siswa diharapkan mendapatkan pembelajaran perilaku. Belajar di balik makna belajar. Para siswa diahrapkan mendapatkan makna pada saat memelajari bahan ajar. Kondisi dapat terjadi dengan rancangan guru. Guru tidak sekedar membicangkan materi ajar. Guru tidak sekedar membawa siswa pada kondisi memiliki pengetahuan dan keterampilan bersastra.

Guru harus cermat memilih bahan kajian yang agar memberikan peluang terhadap siswa untuk merespons. Bahan ajar yang di dalamnya telah merujuk pada kejelasan karakter yang diinginkan dimiliki siswa. Tentu saja kepemilikannya memerlukan waktu. Proses pembelajaran sebagai media pencapaiannya. Proses pembelajaran yang telah dipersiapkan dengan langkahlangkah yang diprediksi dapat membentuk karakter siswa yang diharapkan.

Penulis sajikan bahan kajian yang memberikan ajaran berbuat baik. Sikap arif diharapkan dapat diperoleh siswa. Setidaknya harapan berperilaku arif dapat dicapai siswa dengan memperilakukan dalam kegiatan sehari-hari. Di bawah ini proses pembelajaran Gurindam XII. Gurindam termasuk puisi lama. Siswa pada masa sekarang tidak mengenal puisi lama. Oleh karena harus dikenalkan karena gurindam XII ini padat makna.

Mengapa Gurindam XII? Beberapa pertimbangan dapat disampaikan. Pertama, menjaga hubungan antara generasi sekarang dengan generasi masa lalu. Anak-anak sekarang tidak begitu mengenal kemampuan generasi terdahulunya. Generasi sebelumnya telah banyak berbuat untuk bangsa ini. Mereka menggunakan pikiran dan perasaan untuk bekal bagi generasi berikutnya. Guru berkewajiban mengenalkan karya generasi zaman dahulu. Warisan budaya berbentuk karya sastra tidak lengkang kena waktu. Karya itu dapat didiskusikan dengan berbagai pandangan. Inti karya para penayir zaman dahulu dapat dipilih untuk dibincangkan dan diterapkan dalam perilaku kekinian. Mengenal bahasa secara langsung tidak akan menyulitkan para siswa. Mereka dapat menemukan kalimat-kalimat yang berbeda dengan bahasa Indonesia modern. Kedua, berkenalan dengan bahasa Melayu yang merupakan cikal bakal bahasa Indenesia. Ketiga, mengenal cara orang zaman dahulu bertutur melalui puisi. Siswa diajak mengenal struktur puisi lama. Apa yang menyebabkan puisi lama ini tetap bertahan, dapat dibincangkan melalui berbagai cara. Keempat, gurindam XII sebuah karya yang dapat dijadikan sebagai renungan untuk diaplikasikan dalam perilaku para siswa zaman sekarang. Pada tahap ini siswa diajak untuk menemukan butir-butir penting yang terdapat dalam Gurindam XII. Guru mengajak siswa belajar menerapkan bagian pokok Gurindam XII dalam perilaku sehari-hari. Pada posisi inilah diharapkan dengan cara tepat guru dapat memerlihatkan belajar arif dari Gurindam XII.

Pada bagian selanjutnya penulis sajikan salah satu alternatif pembelajaran Gurindam XII dengan tekanan pada peluang siswa untuk belajar arif. Langkah pembelajaran ini dikutip dari Rozak \& Rasyad (2016:72-92).

Langkah pertama, siswa dikenalkan dengan pengarangnya, yaitu Raja Ali Haji. Raja Ali Haji bin Raja Haji Ahmad atau cukup dengan nama penanya Raja Ali Haji (lahir di Selangor, 
1808 - meninggal di Pulau Penyengat, Kepulauan Riau,1873). Siswa diminta memahami latar belakang lahirnya Gurindam XII.

\section{INILAH GURINDAM DUABELAS NAMANYA}

Segala puji bagi Tuhan seru sekalian alam serta shalawatnya Nabi yang akhirul jaman serta keluarganya dan sahabatnya sekalian adanya.

Amma ba'du daripada itu maka tatkala sampailah Hijratun Nabi 1263 Sanah kepada dua puluh tiga hari bulan Rajab hari Selasa mana telah ta'ali kepada kita yaitu Raja Ali Haji mengarang satu gurindam cara Melayu yaitu yang boleh juga jadi diambil faedah sedikit-sedikit daripada perkataannya itu pada orang yang ada menaruh akal maka adalah banyaknya gurindam itu hanya duabelas pasal di dalamnya.

\section{Syahdan}

Adalah beda antara gurindam dengan syair itu aku nyatakan pula bermula arti syair Melayu itu perkataan yang bersajak yang serupa dua berpasang pada akhirnya dan tiada berkehendak pada sempurna perkataan pada satu-satu pasangnya bersalahan dengan gurindam.

Adapun arti gurindam itu yaitu perkataan yang bersajak juga pada akhir pasangannya tetapi sempurna perkataannya dengan satu pasangannya sahaja jadilah seperti sajak yang pertama itu syarat dan sajak yang kedua itu jadi seperti jawab.

Bermula inilah rupanya syair.

Dengarkan tuan suatu rencana

Mengarang di dalam gundah gulana

Barangkali gurindam kurang kena

Tuan betulkan dengan sempurna

Inilah arti gurindam yang di bawah syatar ini

Persamaan yang indah-indah

Yaitu ilmu yang memberi faedah

Aku hendak bertutur

Akan gurindam yang beratur

Sebuah pengantar dari penyair yang bersahaja, rendah hati, tidak sombomg, dan membuka hatinya bagi semua perbaikan syairnya. Perkenalan yang runtun, sederahana, dan kena sasaran. Penyair menyampaikan apa yang akan ditulisnya (Adapun arti gurindam itu yaitu perkataan yang bersajak juga pada akhir pasangannya/tetapi sempurna perkataannya dengan satu/pasangannya sahaja jadilah seperti sajak/yang pertama itu syarat dan sajak yang kedua itu jadi seperti jawab). Penyair ini tidak merasa dirinya pintar. Dia meminta pembaca memahami kelemahannya dan sudilah menyampaikan perbaikannya (Dengarkan tuan suatu rencanal Mengarang di dalam gundah gulana/Barangkali gurindam kurang kena/Tuan betulkan dengan sempurna.). Guru mengajak para siswa mencermati isi kata pengantar yang terdapat pada 
Gurindam ini. Guru mengajak para siswa untuk memahami karakter penulis yang dapat ditiru. Karakter ini berlaku sepanjang masa; tidak sombong, memberi tahu isi yang akan dikomunikasikan, rendah hati, siap menerima masukan

Langkah kedua, siswa diajak untuk membaca pasal demi pasal. Pembacaan ini penting sebagai pengenalan secara menyeluruh isi Gurndam XII. Guru membiarkan siswa membaca dalam hati. Tanya jawab dilaksanakan guru secara indidividu. Membaca senyap memberikan kesempatan kepada para siswa untuk memahami menurut kemampuannya. Pengalaman baca ini akan memberikan kesempatan mencatat inti yang terkait pada dirinya. Para siswa mungkin akan mendapatkan kesulitan memahami bahasa yang digunakan pada Gurindam XII ini. Akan tetapi, sebenarnya tidak terlalu berbeda dengan bahasa sekarang. Sebagai contoh disajikan pasal pertama (secara utuh Gurindam XII disajikan pada lampiran).

\title{
INI GURINDAM PASAL YANG PERTAMA
}

\author{
Barang siapa tiada memegang agama \\ Segala-gala tiada boleh dibilang nama \\ Barang siapa mengenal yang empat \\ Maka yaitulah orang yang ma'rifat \\ Barang siapa mengenal Allah \\ Suruh dan tegaknya tiada ia menyalah \\ Barang siapa mengenal diri \\ Maka telah mengenal akan Tuhan yang bahri \\ Barang siapa mengenal dunia \\ Tahulah ia barang yang terpedaya \\ Barang siapa mengenal akhirat \\ Tahulah ia dunia mudharat
}

Para siswa tidak akan mendapat kesulitan berarti mamahami makna kata yang terdapat pada Gurindam XII, pasal pertama.

Langkah ketiga adalah melisankan gurindam XII. Pada tahap ini siswa diajak untuk mengucapkan setelah membaca dalam hati. Langkah ini diperlukan untuk mengetahui pemahaman siswa sebelum membahas isi gurindam. Guru sebaiknya membiarkan siswa melisankan menurut pemahamannya.

\section{Langkah keempat mendiskusikan isi Gurindam XII.}

Pada langkah ini para siswa dibagi menjadi beberapa kelompok. Membincangkan makna gurindam dalam kelompok harus betul-betul berjalan. Oleh karena itu, para siswa melakukan kegiatan mandiri sebelum melakukan disekusi kelompok. Pada kegiatan mandiri guru membekali siswa dengan beberapa pertanyaan di bawah ini.

(1) Tuliskan pengertian gurindam menurut penyair!

(2) Untuk siapa sebenarnya gurindam itu ditulis? Lengkapi jawaban kalian dengan alasan!

(3) Bagaimana penyair memandang pembaca? Lengkapi jawaban kalian dengan alasan! 
(4) Bagaimana sikap penyair dalam menyampaikan nasihatnya? Lengkapi jawaban kalian dengan alasan!

(5) Perhatikan bait terakhir gurindam itu! Apa fungsinya? Lengkapi jawaban kalian dengan alasan!

(6) Manfaat apa yang dapat kalian ambil dari seluruh isi gurindam ini!

(7) Apakah terdapat bagian dari gurindam ini yang dapat kalian contoh untuk diterapkan dalam kehidupan sehari-hari!

Pada saat diskusi kelompok guru membekali format yang harus diisi setelah diskusi. Froamt ini untuk keseragaman, tetapi guru tidak menutup peluang gagasan para siswa.

\begin{tabular}{|c|c|}
\hline Pasal ke- & Maksud \\
\hline 1. & \\
\hline 2. & \\
\hline 3. & \\
\hline 4. & $\begin{array}{l}\text { - jangan bercakap bohong sebab ia menggambarkan mulut yang } \\
\text { berpenyakit kulit ( yang berbau busuk ) } \\
\text { - manusia hendaklah kenal diri sendiri untuk mengelakkan kecelakaan } \\
\text { (hina) } \\
\text { - manusia jangan bersikap kikir } \\
\text { - jangan bersikap kasar apabila diri mempunyai jabatan dan kedudukan } \\
\text { yang tinggi. } \\
\text { - manusia jangan bersikap bawel dengan mengeluarkan kata-kata yang } \\
\text { kurang sopan. } \\
\text { - Manusia hendaklah mengakui kelemahan diri sendiri untuk } \\
\text { menghidari diperbincangkan oleh orang lain. }\end{array}$ \\
\hline 5. & \\
\hline 6. & \\
\hline 7. & \\
\hline 8. & \\
\hline 9. & \\
\hline 10. & \\
\hline 11. & \\
\hline 12. & \\
\hline
\end{tabular}


Langkah kelima, membicarakan gurindam sebagai genre khas. Guru mengajak siswa mencermati ciri khas gurindam dibandingkan dengan puisi lama yang lain. Guru mengenalkan bentuk puisi lama yang lain. Langkah ini untuk merumuskan struktur, isi, dan bahasa.

\section{PANTUN}

\section{KADI, HULUBALANG, PEGAWAI}

Berperak ke tengah kota

Tempat bertanam padi

Jika banyak kitab tak terbaca

Tiada sah menjadi kadi

Burung kenari berkekah

Berkekah di tengah padang

Jika tak berani menjarah

Tiada sah menjadi hulubalang

Lalu bertempat orang Kubung

Kubaruh (kebawah) membawa petai,

Jika tak tahu kata penghubung,

Tiada sah menjadi pegawai

Puisi Lama, Sutan Takdir Alisyahbana

\section{SYAIR}

\section{SYAIR PERAHU}

Inilah gerangan suatu madah mengarangkan syair terlalu indah membetuli jalan tempat berpindah

di sanalah I'tikat (iman) diperbetuli sudah

Wahai muda, kenali dirimu

ialah perahu tamsil tubuhmu

tiadalah berapa lama hidupmu

ke akhirat jua kekal diammu

Hai muda arif budiman

hasilkan kemudia dengan pedoman

alat perahu jua engkau kerjakan

itulah jalan membetuli insan

Perteguh jua perahumu

hasilkan bekal air dan kayu 
dayung pengayuh taruh di situ

supaya laju perahumu

(sumber : Sutan Takdir Alisyahbana, Puisi Lama)

\section{GURINDAM XII}

\section{INI GURINDAM PASAL YANG PERTAMA}

Barang siapa tiada memegang agama

Segala-gala tiada boleh dibilang nama

Barang siapa mengenal yang empat

Maka yaitulah orang yang ma'rifat

Barang siapa mengenal Allah

Suruh dan tegaknya tiada ia menyalah

Barang siapa mengenal diri

Maka telah mengenal akan Tuhan yang bahri

Barang siapa mengenal dunia

Tahulah ia barang yang terpedaya

Barang siapa mengenal akhirat

Tahulah ia dunia mudharat

\section{2}

\section{INI GURINDAM PASAL YANG KEDUA}

Barang siapa mengenal yang tersebut

Tahulah ia makna takut

Barang siapa meninggalkan sembahyang

Seperti rumah tiada bertiang

Barang siapa meninggalkan puasa

Tidaklah mendapat dua termasa

Barang siapa meninggalkan zakat

Tiadalah hartanya beroleh berkat

Barang siapa meninggalkan haji

Tiadalah ia menyempurnakan janji

3

INI GURINDAM PASAL YANG KETIGA

Apabila terpelihara mata

Sedikitlah cita-cita

Apabila terpelihara kuping

Khabar yang jahat tiadalah damping

Apabila terpelihara lidah

Niscaya dapat daripadanya faedah

Bersungguh-sungguh engkau memeliharakan tangan 
Daripada segala berat dan ringan

Apabila perut terlalu penuh

Keluarlah fi'il yang tidak senonoh

Anggota tengah hendaklah ingat

Di situlah banyak orang yang hilang semangat

Hendaklah peliharakan kaki

Daripada berjalan yang membawa rugi

Siswa diminta (1) membaca dengan cermat ketiga jenis puisi di atas, (2) mencatat kekhasan masing-masing puisi itu, (3) memerhatikan unsur isi, struktur/bentuk dan bahasa (kalimat, pilihan kata), dan (4) merumuskan secara khusus kekhasan gurindam dua belas. Guru memberikan fromat untuk diisi siswa agar seragam dalam menyusun laporan

\begin{tabular}{|l|l|l|l|l|}
\hline No. & \multicolumn{1}{|c|}{ Unsur } & Pantun & Syair & Gurindam XII \\
\hline 1 & Struktur/bentuk & & & \\
\hline 2 & Isi & & & \\
\hline 3 & Bahasa & & & \\
\hline
\end{tabular}

Langkah keenam, merefleksi. Guru dan siswa membincangkan makna secara menyulurh yang terdapat pada Guridnam XII yang dihubungkan dengan kehidupan. Guru mengajukan beberapa pertanyaan.

a. Perhatikan sekali lagi isi gurindam itu kemudian kalian deskripsikan kehidupan masyarakat pada saat itu!

b. Apakah gurindam itu berfungsi dalam kehidupan masyarakat pada saat itu? Lengkapi jawaban kalian dengan alasan!

c. Bagaimana dengan nasihat yang terkandung dalam gurindam itu? Apakah nasihat itu masih relevan dengan masa kini? Lengkapi jawaban kalian dengan alasan!

d. Menurut pengamatan kalian, masih adakah orang tua yang menasihati anaknya dengan cara seperti yang tertera dalam gurindam? Lengkapi jawaban kalian dengan alasan!

e. Kemukakan kesan kalian terhadap gurindam XII dan terhadap pengarangnya, Raja Ali Haji!

\section{PENUTUP}

1. Pembelajaran memberikan peluang bagi guru dan siswa untuk sama-sama belajar. Belajar tidak mengenal batas selesai. Banyak hal yang menantang manusia untuk dipelajari. Segala hal yang terjadi di dunia ini bergeraks etiap saat dan gerakan itu memunculkan hal yang baru. Kebaruan itu perlu dipelajari dan kebaruan itu harus diepalajari. Salah satu media pembelajaran adalah melalui proses interaksi di sekolah yang telah dijadwalkan. 
Guru dan siswa mempunyai kesempatan untuk mendiskusikan berbagai hal yang berhubungan dengan materi ajar. Materi ajar itu bagian dari persiapan hidup.

2. Sastra memberikan peluang kepada guru dan siswa untuk memeroleh pengalaman melalui diskusi. Muatan sastra pada kurikulum telah disusun dengan cermat melalui tahapan. Guru dapat mencermati hubungan materi sastra dengan ilmu dan pengalaman. Kedua kompetensi ini dapat menerjemahkan kompetensi inti yang terdapat dalam kurikulum. Guru harus memerhitungkan semua aspek pada saat menafsirkan kurikulum. Kurikulum menyiapkan bahan yang masih mentaah, tetapi cukup memberikan arah bagi guru. Kajian guru dapat merupakan gambaran proses belajar mengajar di kelas.

3. Bahan ajar merupakan media fungsional antara siswa dan guru serta anatara siswa. Interaksi menentukan kualitas pembelajaran. Interaksi ditentukan

\section{RUJUKAN}

\section{Al-Quran}

Rasyad, A. R. (2016). Pembelajaran Sastra Berbasis Teks. Yogyakarta: Farm Publishing. Tomlinson, B. (2013). Developing Materials for Language Teaching. London, New Delhi, New York, Sydney: Bloomsbury.

\section{LAMPIRAN}

\section{INILAH GURINDAM DUABELAS NAMANYA}

Segala puji bagi Tuhan seru sekalian alam serta shalawatnya Nabi yang akhirul jaman serta keluarganya dan sahabatnya sekalian adanya.

Amma ba'du daripada itu maka tatkala sampailah Hijratun Nabi 1263 Sanah kepada dua puluh tiga hari bulan Rajab hari Selasa mana telah ta'ali kepada kita yaitu Raja Ali Haji mengarang satu gurindam cara Melayu yaitu yang boleh juga jadi diambil faedah sedikit-sedikit daripada perkataannya itu pada orang yang ada menaruh akal maka adalah banyaknya gurindam itu hanya duabelas pasal di dalamnya.

\section{Syahdan}

Adalah beda antara gurindam dengan syair itu aku nyatakan pula bermula arti syair Melayu itu perkataan yang bersajak yang serupa dua berpasang pada akhirnya dan tiada berkehendak pada sempurna perkataan pada satu-satu pasangnya bersalahan dengan gurindam.

Adapun arti gurindam itu yaitu perkataan yang bersajak juga pada akhir pasangannya tetapi sempurna perkataannya dengan satu pasangannya sahaja jadilah seperti sajak yang pertama itu syarat dan sajak yang kedua itu jadi seperti jawab.

Bermula inilah rupanya syair. 
Dengarkan tuan suatu rencana

Mengarang di dalam gundah gulana

Barangkali gurindam kurang kena

Tuan betulkan dengan sempurna

Inilah arti gurindam yang di bawah syatar ini

Persamaan yang indah-indah

Yaitu ilmu yang memberi faedah

Aku hendak bertutur

Akan gurindam yang beratur

\section{INI GURINDAM PASAL YANG PERTAMA}

Barang siapa tiada memegang agama

Segala-gala tiada boleh dibilang nama

Barang siapa mengenal yang empat

Maka yaitulah orang yang ma'rifat

Barang siapa mengenal Allah

Suruh dan tegaknya tiada ia menyalah

Barang siapa mengenal diri

Maka telah mengenal akan Tuhan yang bahri

Barang siapa mengenal dunia

Tahulah ia barang yang terpedaya

Barang siapa mengenal akhirat

Tahulah ia dunia mudharat

2

\section{INI GURINDAM PASAL YANG KEDUA}

Barang siapa mengenal yang tersebut

Tahulah ia makna takut

Barang siapa meninggalkan sembahyang

Seperti rumah tiada bertiang

Barang siapa meninggalkan puasa

Tidaklah mendapat dua termasa

Barang siapa meninggalkan zakat

Tiadalah hartanya beroleh berkat

Barang siapa meninggalkan haji

Tiadalah ia menyempurnakan janji

\section{3}

\section{INI GURINDAM PASAL YANG KETIGA}

Apabila terpelihara mata

Sedikitlah cita-cita

Apabila terpelihara kuping 
Khabar yang jahat tiadalah damping

Apabila terpelihara lidah

Niscaya dapat daripadanya faedah

Bersungguh-sungguh engkau memeliharakan tangan

Daripada segala berat dan ringan

Apabila perut terlalu penuh

Keluarlah fi'il yang tidak senonoh

Anggota tengah hendaklah ingat

Di situlah banyak orang yang hilang semangat

Hendaklah peliharakan kaki

Daripada berjalan yang membawa rugi

\section{4 \\ INI GURINDAM PASAL YANG KEEMPAT}

Hati itu kerajaan di dalam tubuh

Jikalau zalim segala anggota tubuh pun rubuh

Apabila dengki sudah bertanah

Datanglah daripadanya beberapa anak panah

Mengumpat dan memuji hendaklah pikir

Di situlah banyak orang yang tergelincir

Pekerjaan marah jangan dibela

Nanti hilang akal di kepala

Jika sedikitpun berbuat bohong

Boleh diumpamakan mulutnya itu pekung

Tanda orang yang amat celaka

Aib dirinya tiada ia sangka

Bakhil jangan diberi singgah

Itulah perompak yang amat gagah

Barang siapa yang sudah besar

Janganlah kelakuannya membuat kasar

Barang siapa perkataan kotor

Mulutnya itu umpama ketor

Di manakah salah diri

Jika tidak orang lain yang berperi

Pekerjaan takbur jangan direpih

Sebelum mati didapat juga sepih

5

INI GURINDAM PASAL YANG KELIMA

Jika hendak mengenal orang berbangsa

Lihat kepada budi dan bahasa

Jika hendak mengenal orang yang berbahagia

Sangat memeliharakan yang sia-sia

Jika hendak mengenal orang mulia

Lihatlah kepada kelakuan dia 
Jika hendak mengenal orang yang berilmu

Bertanya dan belajar tiadalah jemu

Jika hendak mengenal orang yang berakal

Di dalam dunia mengambil bekal

Jika hendak mengenal orang yang baik perangai

Lihat pada ketika bercampur dengan orang ramai

\section{6}

INI GURINDAM PASAL YANG KEENAM

Cahari olehmu akan sahabat

Yang boleh dijadikan obat

Cahari olehmu akan guru

Yang boleh tahukan tiap seteru

Cahari olehmu akan isteri

Yang boleh menyerahkan diri

Cahari olehmu akan kawan

Pilih segala orang yang setiawan

Cahari olehmu akan abdi

Yang ada baik sedikit budi

\section{7}

\section{INI GURINDAM PASAL YANG KETUJUH}

Apabila banyak berkata-kata

Di situlah jalan masuk dusta

Apabila banyak berlebih-lebihan suka

Itu tanda hampirkan duka

Apabila kita kurang siasat

Itulah tanda pekerjaan hendak sesat

Apabila anak tidak dilatih

Jika besar bapanya letih

Apabila banyak mencat (mencacat?) orang

Itulah tanda dirinya kurang

Apabila orang yang banyak tidur

Sia-sia sajalah umur

Apabila mendengar akan kabar

Menerimanya itu hendaklah sabar

Apabila mendengar akan aduan

Membicarakannya itu hendaklah cemburuan

Apabila perkataan yang lemah lembut

Lekaslah segala orang mengikut

Apabila perkataan yang amat kasar

Lekaslah orang sekalian gusar

Apabila pekerjaan yang amat benar

Tidak boleh orang berbuat onar 
INI GURINDAM PASAL YANG KEDELAPAN

Barang siapa khianat akan dirinya

Apalagi kepada lainnya

Kepada dirinya ia aniaya

Orang itu jangan engkau percaya

Lidah suka membenarkan dirinya

Daripada yang lain dapat kesalahannya

Daripada memuji diri hendaklah sabar

Biar daripada orang datangnya kabar

Orang yang suka menampakkan jasa

Setengah daripadanya syirik mengaku kuasa

Kejahatan diri disembunyikan

Kebajikan diri diamkan

Ke'aiban orang jangan dibuka

Ke'aiban diri hendaklah sangka

9

\section{INI GURINDAM PASAL YANG KESEMBILAN}

Tahu pekerjaan tak baik tetapi dikerjakan

Bukannya manusia yaitulah syaitan

Kejahatan seorang perempuan tua

Itulah iblis punya penggawa

Kepada segala hamba-hamba raja

Di situlah syaitan tempatnya manja

Kebanyakan orang yang muda-muda

Di situlah syaitan tempat bergoda

Perkumpulan laki-laki dengan perempuan

Di situlah syaitan punya jamuan

Adapun orang tua(h) yang hemat

Syaitan tak suka membuat sahabat

Jika orang muda kuat berguru

Dengan syaitan jadi berseteru

10

\section{INI GURINDAM PASAL YANG KESEPULUH}

Dengan bapa jangan derhaka

Supaya Allah tidak murka

Dengan ibu hendaklah hormat

Supaya badan dapat selamat

Dengan anak janganlah lalai

Supaya boleh naik ke tengah balai 
Dengan kawan hendaklah adil

Supaya tangannya jadi kapil

\section{1}

\section{INI GURINDAM PASAL YANG KESEBELAS}

Hendaklah berjasa

Kepada yang sebangsa

Hendak jadi kepala

Buang perangai yang cela

Hendaklah memegang amanat

Buanglah khianat

Hendak marah

Dahulukan hujjah

Hendak dimalui

Jangan memalui

Hendak ramai

Murahkan perangai

\section{2}

\section{INI GURINDAM PASAL YANG KEDUABELAS}

Raja mufakat dengan menteri

Seperti kebun berpagarkan duri

Betul hati kepada raja

Tanda jadi sebarang kerja

Hukum adil atas rakyat

Tanda raja beroleh inayat

Kasihkan orang yang berilmu

Tanda rahmat atas dirimu

Hormat akan orang yang pandai

Tanda mengenal kasa dan cindai

Ingatkan dirinya mati

Itulah asal berbuat bakti

Akhirat itu terlalu nyata

Kepada hati yang tidak buta

Tamatlah gurindam yang duabelas pasal yaitu karangan kita

Raja Ali Haji pada tahun Hijrah Nabi kita seribu dua ratus enam puluh tiga kepada tiga likur

hari bulan Rajab Selasa jam pukul

lima Negeri Riau Pulau

Penyengat 